\title{
FAKTOR-FAKTOR YANG MEMPENGARUHI PERSEPSI WAJIB PAJAK ORANG PRIBADI TERHADAP ETIKA PENGGELAPAN PAJAK (Studi Empiris pada Wajib Pajak Terdaftar di KPP Pratama Jayapura)
}

\author{
Bryando Helweldery ${ }^{1}$ \\ Theo Allolayuk, SE., M.Si., Ak., CA ${ }^{2}$ \\ Cornelia D. Matani, SE., M.Mgt (Acc) ${ }^{3}$ \\ Jurusan Akuntansi, Fakultas Ekonomi dan Bisnis Universitas Cenderawasih
}

\begin{abstract}
This research aims to determine the influence of taxation, tax-service, and taxation sanctions on tax evasion. The population in this research is a registered taxpayer at KPP Pratama Jayapura. Sampling is done according to the proportions, so that the number of respondents are fulfilled by a certain characteristic of 100 respondents. The data analysis methods used in this study are validity, reliability, classical assumption test, hypothesized test and multiple linear regression. The results showed that partially understanding taxation positively affect tax evasion, while the tax authorities have no positive effect and the taxation sanctions have no positive effect on tax evasion In addition, the research has no simultaneous effect on tax evasion at KPP Pratama Jayapura. The implications of this study show that tax evasion is seen as unethical action to do. The Directorate General of Taxation needs to socialize the importance of taxation understanding to lower tax evasion rates.
\end{abstract}

Keywords : taxpayer's knowledge, service of tax officer, tax sanction, taxpayer's perceptions on tax evasion.

\section{PENDAHULUAN}

Bagi sebagian besar negara termasuk di Indonesia sebagai negara berkembang, pajak merupakan unsur paling penting dalam menopang anggaran penerimaan negara. Dalam melaksanakan dan merealisasikan rencana pembangunan nasional, Pemerintah memerlukan dana yang cukup besar guna mewujudkannya. Direktorat Jenderal (Ditjen) Pajak, instansi pemerintahan di bawah Departemen Keuangan sebagai pengelola sistem perpajakan di Indonesia, berusaha melakukan tugas pokoknya yaitu meningkatkan penerimaan pajak dengan mereformasi pelaksanaan sistem perpajakan menjadi lebih modern. semua pemasukan negara yang berasal dri pajak akan digunakan untuk membiayai semua pengeluaran umum negara, dalam hal ini digunakan untuk mensejahterakan dan memakmurkan rakyat (Waluyo, 2007).

Sementara itu, setiap tahun jumlah pemasukan dari pajak yang disetorkan selalu meningkat dan disisi lain pemerataan dari pajak yang disetor belum dirasakan masyarakat secar adil (Prasetyo, 2010). Suminarsasi (2012) dalam penelitiannya mengemukakan bahwa sistem perpajakan di Indonesia yang belum optimal, disertai pemahaman Wajib Pajak yang masih rendah akan peraturan perpajakan yang berlaku merupakan salah satu faktor yang dapat memicu Wajib Pajak melakukan tax evasion (penggelapan pajak). Munculnya oknum makelar pajak seperti Gayus, Dhana Widyatmika dan banyak petugas lainnya membuat keyakinan wajib pajak atas kinerja pelayanan pajak berkurang sehingga wajib pajak tidak mau membayar pajak karena takut uangnya digelapkan, adanya biaya yang dipungut dan bukan untuk pembangunan negara (Nugroho, 2012).

\footnotetext{
$\overline{{ }^{1} \text { Alumni Jurusan Akuntansi FEB Uncen }}$

${ }^{2}$ Dosen Jurusan Akuntansi FEB Uncen

3 Dosen Jurusan Akuntansi FEB Uncen
} 
Mengacu fenomena seperti itu, maka aparat pajak dituntut untuk memberikan pelayanan yang ramah, adil dan tegas setiap saat kepada wajib pajak serta dapat memupuk kesadaran wajib pajak tentang tanggungjawab membayar pajak (Fikriningrum, 2012).

Hal lain yang perlu diperhatikan adalah pengenaan sanksi dalam peraturan perundang-undangan dibidang perpajakan yang ada di Indonesia. Sanksi pada sistem perpajakan di Indonesia dinilai kurang efektif dan kontra produktif terhadap fungsi anggaran dari pajak dan pengembangan ekonomi sehingga perlu di kaji keberadaan dan efektifitasnya (Purwanto, 2006). Adanya perbedaaan hasil penelitian terdahulu dan maraknya praktik penggelapan pajak mendorong minat penulis untuk melakukan penelitian dengan faktor-faktor pemahaman perpajakan, pelayanan aparat pajak dan sanksi perpajakan terhadap persepsi wajib pajak atas perilaku penggelapan pajak.

\section{TINJAUAN PUSTAKA}

\subsection{Theory of Planned Behavior (TPB)}

Ajzen (1991) dalam Krueger \& Carsrud (1993) mengungkapkan bahwa Theory of Planned Behavior merupakan peningkatan dari Theory of Reasoned Action (1988) yang bertujuan memperlihatkan keterkaitan dari perilaku-perilaku yang dimunculkan oleh setiap individu untuk menanggapi sesuatu. Dalam Theory of Planned Behavior mempunyai variable kontrol keperilakuan yang tidak dimiliki oleh Theoy of Reasoned Action. Variabel kontrol keperilakuan mengartikan bahwa tidak semua tindakan yang diambil oleh setiap individu berada dibawah kendali setiap individu tersebut.

Sehingga dengan sikap setiap individu untuk berperilaku yang baik ketika melaksanakan ketentuan perpajakan, secara langsung memudahkan wajib pajak orang pribadi (wpop) dalam melakukan aktivitas perpajakan dan kemungkinan tidak melakukan tindakan yang melanggar hukum, dalam hal ini kesempatan penggelapan pajak menjadi rendah.

\subsection{Teori Perepsi}

Untuk memahami tentang persepsi terhadap perilaku penggelapan pajak, terlebih dahulu akan diterangkan beberapa konsep tentang persepsi menurut Haidar \& Hutama (2016), yang dimaksud dengan persepsi adalah: Tanggapan langsung dari suatu serapan atau proses seseorang mengetahui tentang beberapa hal melalui pengindraan. Atau secara sempit persepsi ialah sebagai suatu tangkapan rangsang dari luar oleh pengindraan sedangkan persepsi secara meluas ialah sebagai suatu pengertian, pemahaman, dan penafsiran terhadap suatu objek tertentu.

Sehingga nampak adanya pengaruh persepsi dalam membentuk perilaku individu sebagai warga Negara dalam rangka memenuhi kewajiban membayar pajak sesuai dengan perundangundangan yang telah berlaku, sebagai simpulan/konklusi mengenai persepsi setiap individu bahwa persepsi ialah proses menerima, mengorganisasikan, serta mengartikan suatu obyek. Dalam hal ini persepsi setiap individu terhadap perilaku penggelapan pajak ialah proses individu dalam menerima, mengorganisasikan serta mengartikan praktek penggelapan pajak yang dipengaruhi oleh lingkungan sosial setempat yang melingkupi setiap individu tersebut.

\subsection{Etika}

Etika berasal dari bahasa yunani, yang mempunyai arti adat istiadat, perilaku, dan kebiasaan. Dalam pengertian ini etika menyangkut dengan kebiasaan hidup yang sangat baik, baik pada diri seseorang maupun pada suatu masyarakat atau berkelompok. Etika berperan menetapkan apa yang harus dilakukan dan apa yang tidak harus diperbolehkan dilakukan seseorang individu. 
Dalam memandang perilaku penggelapan pajak (tax evasion), Murni, Tarjo dan Muahammad (2013) dalam Rachmadi (2014 mengemukakan bahwa pengalaman-pengalaman wajib pajak dapat menimbulkan kepatuhan ataupun ketidakpatuhan dalam melaksanakan ketentuan perpajakan. McGee (2006) dalam Suminarsasi (2012) menemukan bahwa beberapa negara mengkategorikan penggelapan pajak tidak pernah etis, ada saatnya dipandang etis tergantung pada fakta-fakta dan keadaan atau dipandang selalu etis. Sehingga, perilaku penggelapan pajak akan dipersepsikan sebagai tindakan yang tidak etis dan wajib pajak orang pribadi (wpop) cenderung menghindari tindakan tersebut.

\subsection{Penggelapan Pajak (Tax Evasion)}

Penggelapan pajak (tax evasion) adalah tindakan pidana karena merupakan rekayasa/manipulasi subyek (pelaku) dan objek (transaksi) pajak untuk memperoleh penghematan pajak secara melawan hukum (unlawfull), dan penggelapan pajak bisa diartikan merupakan virus yang melekat pada setiap system pajak yang berlaku dihampir setiap yuridiksi.

\subsection{Pemahaman/Pengetahuan Perpajakan}

Pengetahuan akan peraturan perpajakan sangat berkaitan dengan pembayran pajak. Resmi (2009) mengungkapkan bahwa pemahaman dan pengetahuan tentang peraturan perpajakan adalah proses dimana wajib pajak memahami tentang perpajakan dan menerapkan pengetahuan/pemahaman itu untuk membayar pajak. Syarat-syarat untuk melaksanakan pembayaran pajak adalah: Wajib pajak harus sudah memiliki/mempunyai NPWP, Wajib pajak harus melaporkan SPT.

Secara psikologis dan sadar akan hukum yang ada, Wajib pajak yang melakukan penggelapan pajak pada umumnya bertujuan untuk menghindari jumlah pajak terutang yang harus disetorkan ke kas Negara. Resmi (2009) mengungkapkan bahwa sosialisasi akan Undang-Undang Perpajakan dan sanksi yang diterapkan apabila melanggar ketentuan perpajakan, diharapkan dapat menjadi solusi akan kasus-kasus penggelapan pajak. Dengan demikian, pemahaman/pengetahuan perpajakan sangat berpengaruh atas pola pikir wajib pajak yang akan melakukan kecurangan/penggelapan pajak.

\subsection{Pelayanan Aparat/Pegawai Pajak}

Menurut Wallschutzky (1984) pemberian pelayanan yang baik kepada wajib pajak akan menimbulkan kepatuhan, sedangkan Glaser \& Hildreth (1999) juga mengungkapkan bahwa terdaapt bukti empiris yang menyatakan penduduk bersedia untuk membayar pajak yang tinggi karena layanan yang dapat dipercaya dan yang dilaksanakan dengan baik. Tujuan pelayanan pajak dan sekaligus pemeriksaan pajak berdasarkan Undang-Undang No 28 Tahun 2007 tentang ketentuan umum dan tata cara perpajakan Pasal 29 ayat 1.

Menurut Supadmi (2009) mengenai Pelayanan Prima ialah pelayanan yang dapat memberikan kepuasan kepada Wajib Pajak (WP) dan tetap dalam batas memenuhi standar pelayanan yang dapat dipertanggungjawabkan dan dilakukan secara terus-menerus. Sedangkan yang melakukan tugas pemeriksaan dan memberikan pelayanan pajak dilakukan oleh Pegawai Negeri Sipil (PNS) dilingkungan Direktorat Jenderal Pajak Departemen Keuangan yang diberi tugas, tanggungjawab, wewenang, dan hak secar penuh dari pejabat yang berwenang untuk melaksanakan pemeriksaan pajak serta penyidikan tindak pidana perpajakan. 


\subsection{Sanksi Perpajakan}

Sanksi perpajakan adalah "suatu tindakan yang diberikan kepada Wajib Pajak (WP) atau pejabat yang berhubungan dengan pajak yang melakukan pelanggaran baik secara sengaja maupun karena alpa, sanksi perpajakan merupakan jaminan bahwa ketentuan peraturan perundang-undangn perpajakan akan dipatuhi” Tjahjono (2005). Dengan demikian sanksi perpajakan merupakan alat agar Wajib Pajak (WP) tidak melanggar norma perpajakan.

\subsection{Penelitian Terdahulu dan Pengembangan Hipotesis}

\subsubsection{Pengaruh Pemahaman Perpajakan Terhadap Persepsi Wajib Pajak Atas Perilaku Penggelapan Pajak}

Pengaruh pemahaman perpajakan oleh Wajib Pajak Orang Pribadi terhadap persepsi atas perilaku penggelapan pajak dapat dikembangkan dengan melihat seberapa besar pemahaman ketentuan perpajakan dapat dipahami oleh wajib pajak, dimengerti dan dipatuhi untuk kemudian dilaksanakan. Tujuannya agar harapannya ke depan, praktik penggelapan pajak dapat diminimalisir serendah mungkin dan wajib pajak memahami perilaku tersebut melanggar hukum dan tidak etis untuk dilakukan.

Mengacu pada teori persepsi (Gibson, 2001), timbulnya persepsi oleh individu dipengaruhi oleh stimulus-stimulus, salah satunya pemahaman terhadap objek. Kaitannya dengan objek penelitian ini adalah praktik penggelapan pajak, dimana wajib pajak akan menganggap buruk, tidak etis untuk dilakukan dan cenderung menghindari suatu tindakan yang melanggar ketentuan apabila pemahaman yang dimilikinya semakin baik. Berdasarkan uraian di atas, dirumuskan hipotesis sebagai berikut:

$\mathrm{H}_{1}$ : Persepsi Wajib Pajak tentang pemahaman perpajakan berpengaruh positif terhadap etika penggelapan pajak

\subsubsection{Pengaruh Pelayanan Aparat Pajak Terhadap Persepsi Wajib Pajak Atas Perilaku Penggelapan Pajak}

Peningkatan pelayanan aparat pajak idealnya akan memberikan pengaruh yang signifikan bagi Wajib Pajak untuk tidak melakukan penggelapan pajak dan memandang penggelapan pajak sebagai tidakan ilegal, tidak etis dan melanggar hukum. Di sisi lain, dengan semakin baiknya pelayanan yang diberikan kepada wajib pajak secara langsung memudahkan tugas Direktorat Jenderal Pajak sebagai instansi pengelola dana pajak.

Kemauan wajib pajak dalam memenuhi kewajibannya membayar pajak tergantung pada bagaimana petugas pajak memberikan mutu pelayanan yang terbaik kepada Wajib Pajak (Hardiningsih, 2011). Hal ini sesuai dengan bahasan dari Theory of Planned Behavior (TPB) terkait niat berperilaku (behavior intention) dari wajib pajak dalam memenuhi kewajiban perpajakan sudah selayaknya didukung oleh mutu dari pelayanan aparat pajak yang prima dan sebaik mungkin. Dari pemikiran diatas, hipotesis kedua yang diusulkan adalah sebagai berikut:

$\mathrm{H}_{2}$ : Persepsi wajib pajak tentang pelayanan aparat pajak berpengaruh positif terhadap etika penggelapan pajak.

\subsubsection{Pengaruh Sanksi Perpajakan Terhadap Persepsi Wajib Pajak Atas Perilaku Penggelapan Pajak}

Semakin besarnya denda yang dibebankan akan mendorong wajib pajak untuk berperilaku tidak patuh, dan semakin banyak celah kesempatan yang dimiliki wajib pajak untuk melakukan penggelapan pajak. Pareek (2001) mengungkapkan bahwa persepsi individu akan suatu objek terbentuk atas adanya penafsiran kesan inderawi dan pengaruh pengalaman yang dialami. Kaitannya dengan penelitian ini, diperoleh hubungan bahwa pemberian sanksi perpajakan yang 
berat akan menimbulkan persepsi dalam diri pembayar pajak bahwa pajak merupakan ancaman, karena mengurangi jumlah pendapatan yang diperoleh.

Dalam hal ini dapat diindikasikan bahwa tindakan membayar pajak akan merugikan diri pribadi dan wajib pajak cenderung melakukan upaya tidak melaporkan jumlah pajak disetor yang semestinya. Berdasarkan uraian di atas, maka dirumuskan hipotesis sebagai berikut:

H3 : Persepsi wajib pajak tentang sanksi perpajakan yang berat berpengaruh positif terhadap etika penggelapan pajak.

\subsection{Model Penelitian}

Selanjutnya kerangka pemikiran teoritis penelitian disajikan pada gambar 1 sebagai berikut:

\section{Gambar 1}

Kerangka Pemikiran Teoritis

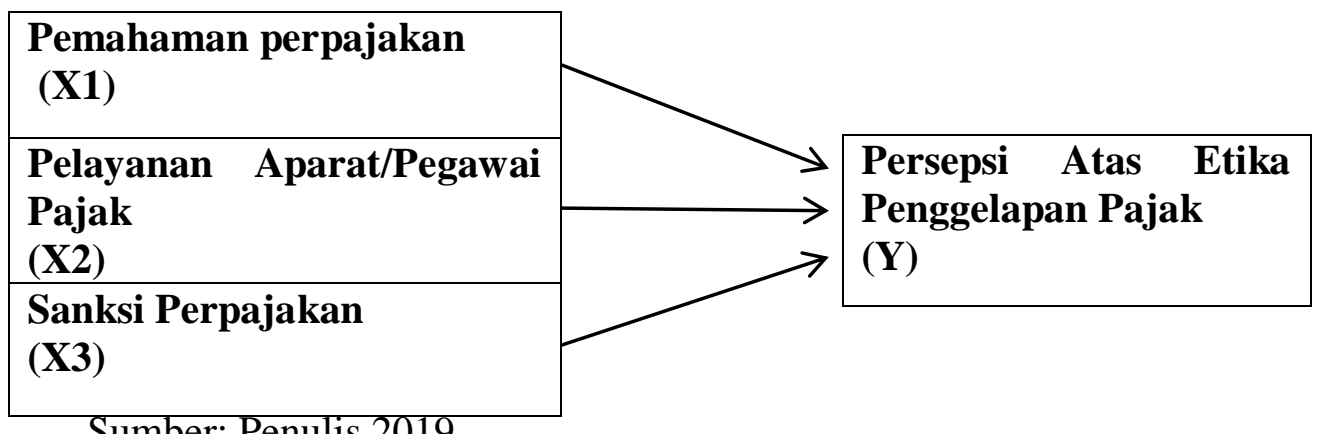

Sumber: Penulis 2019

\section{METODE PENELITIAN}

\subsection{Jenis dan Sumber Data}

Jenis data yang dipakai dalam peniltian ini ialah data primer, dimana data tersebut berupa angka yang tertulis didalam skala kuisioner yang kemudian diolah. Data yang diperoleh dari hasil kuisioner dalam bentuk pernyataan yang dibagikan kepada wajib pajak (responden) untuk mengetahui setiap resonden masing-masing individu. Sumber data penelitian ini ialah wajib pajak orang pribadi yang terdaftar di Kpp Pratama Jayapura.

\subsection{Penentuan Sampel}

Jenis sampel yang dilakukan adalah Accidental Sampling, dimana teknik tersebut menentukan sampel berdasarkan kebetulan/insidental bertemu dengan penelitti dapat digunakan sebagai sampel, bila dipandang orang yang kebetulan ditemui itu cocok sebagai sumber data. Pengambilan sampel dilakukan sesuai proporsinya, sehingga sudah terpenuhi jumlah responden yang dimaksud dengan karakteristik tertentu (Umar, 2003). Berdasarkan hasil observasi yang telah dilakukan sesuai maka ditetapkan jumlah responden sebanyak 100 responden.

\subsection{Variabel Penelitian}

Penelitian ini menggunakan tiga variabel independen dan satu variabel dependen. Variabel independen dalam penelitian ini terdiri dari pemahaman perpajakan, pelayanan aparat pajak dan sanksi perpajakan, sedangkan variabel terikatnya adalah persepsi atas perilaku penggelapan pajak.Skala pengukuran yang digunakan untuk variabel-variabel tersebut adalah skala Likert 5 poin. 


\subsection{Metode Analisis}

Analisis yang digunakan dalam penelitian ini adalah :

1. Statistik Deskriptif. Pengujian statistik yang digunakan dalam penelitian untuk menentukan nilai minimum, maksimum, nilai rata-rata (mean) dan simpangan baku (standard deviation).

- Uji Asumsi Klasik. Meliputi hal sebagai berikut :

a. Normalitas. Metode untuk mengetahui kenormalan model regresi adalah dengan One sample Kolmogrov-Smirnov test dan Normal P-Plot.

b. Multikolinearitas. Untuk mengetahui ada atau tidaknya gejala multikolinearitas, dengan melihat nilai Varians Inflation Factor (VIF) dan Tolerance.

c. Heteroskedastisitas. Metode untuk mengetahui ada atau tidaknya heteroskedastisitas dengan melihat grafik scatterplot. Selain dengan melihat grafik scatterplot juga menggunakan uji Glejser sebagai uji tambahan.

3. Uji Regresi Berganda. Mengingat penelitian ini menggunakan tiga variabel bebas, maka model persamaan regresi adalah sebagai berikut :

$$
\mathrm{Y}=\alpha+\mathrm{b}_{1} \mathrm{X}_{1}+\mathrm{b}_{2} \mathrm{X}_{2}+\mathrm{b}_{3} \mathrm{X}_{3}+\mathrm{e}
$$

Keterangan :

$\mathrm{Y}=$ Persepsi Wajib Pajak atas perilaku penggelapan pajak

b1..b3 = koefisien arah regresi

a $\quad=$ konstanta

$\mathrm{X} 1=$ Pemahaman perpajakan

$\mathrm{X} 2=$ Pelayanan aparat pajak

$\mathrm{X} 3=$ Sanksi perpajakan

$\mathrm{e}=$ Error

4. Koefisien Determinasi. Digunakan untuk mengukur kemampuan yang terdapat pada model regresi dalam menjelaskan variabel dependen penelitian (Ghozali, 2006). Besarnya nilai Adjusted $R$ square dapat naik atau turun dengan adanya penambahan variabel baru.

\section{HASIL PENELITIAN DAN PEMBAHASAN}

\subsection{Deskripsi Sampel Penelitian}

Jumlah kuesioner yang disebarkan kepada responden sebanyak 100 kuesioner. Sampel akhir pengamatan adalah sebanyak 100 kuesioner,

\section{Tabel 1}

Hasil Distribusi Kuesioner

\begin{tabular}{lcc}
\hline Keterangan & Jumlah & Persentase \\
\hline $\begin{array}{l}\text { Kuisioner yang disebar } \\
\text { dikurangi: }\end{array}$ & 100 & $100 \%$ \\
Kuisioner yang tidak lengkap & & \\
$\begin{array}{l}\text { Kuisioner yang tidak kembali } \\
\text { Sampel akhir pengamatan }\end{array}$ & 100 & 100 \\
\hline
\end{tabular}

Sumber: Pengolahan data hasil penelitian 
Dari tabel 1 di atas diketahui bahwa sebanyak 100\% dari keseluruhan kuesioner atau sebesar 100 kuesioner dapat diolah. Selanjutnya disajikan hasil statistik deskriptif penelitian untuk mengetahui hasil kisaran data dan kisaran teoritis penelitian. Hasil statistik deskriptif ditunjukkan dalam tabel 2 sebagaimana di bawah ini :

Tabel 2

Hasil Statistik Deskriptif

\begin{tabular}{|c|c|c|c|c|c|c|c|}
\hline \multirow{2}{*}{\multicolumn{2}{|c|}{ Keterangan }} & \multicolumn{2}{|c|}{$\begin{array}{l}\text { Kisaran teoritis } \\
\text { Std. Dev }\end{array}$} & \multicolumn{2}{|c|}{ Kisaran Data } & & \\
\hline & & Min & Mean & Min & Max & & \\
\hline $\mathrm{X} 1$ & 100 & 18,00 & 36 & 18 & 45 & 36,65 & 9,044 \\
\hline $\mathrm{X} 2$ & 100 & 17,00 & 25 & 17 & 30 & 25,47 & 5,234 \\
\hline $\mathrm{X} 3$ & 100 & 16,00 & 21 & 16 & 25 & 21,12 & 2,479 \\
\hline $\mathrm{Y}$ & 100 & 12,00 & 17 & 14 & 20 & 17,18 & 1,908 \\
\hline Valid & 100 & & & & & & \\
\hline
\end{tabular}

Sumber: Data primer yang diolah, 2019

Berdasarkan tabel 2 di atas, nilai jawaban responden terhadap persepsi perilaku penggelapan pajak (Y) mempunyai nilai kisaran data minimum 18, nilai maksimum sebesar 45 dan rata-rata 27,29. Nilai standar deviasi diperoleh sebesar 5,586. Hal ini menunjukkan penyimpangan data relatif kecil pada variabel pemahaman perpajakan.

Pada tabel 2 diatas dapat dilihat bahwa variabel dependen Penggelapan Pajak memiliki nilai terendah sebesar 12,00 dan nilai tertinggi sebesar 20,00 dengan nilai rata-ratanya sebesar 17,18 dan standar deviasinya (tingkat sebaran data) sebesar 1,90. Variabel independen Pemahaman Perpajakan memiliki nilai terendah sebesar 18,00 dan nilai tertinggi sebesar 45,00 dengan nilai rata-ratanya sebesar 36,65 dan standar deviasinya sebesar 9,04.

Variabel independen Pelayanan Aparat Pajak memiliki nilai terendah sebesar 17,00 dan nilai tertinggi sebesar 30,00 dengan nilai rata-ratanya sebesar 25,47 dan standar deviasinya sebesar 5,23. Variabel independen Sanksi Perpajakan memiliki nilai terendah sebesar 16,00 dan nilai tertinggi sebesar 25,00 dengan nilai rata-ratanya sebesar 21,12 dan standar deviasinya sebesar 2,47.

\subsection{Hasil Pengujian Hipotesis}

Tabel 3

Koefisien Determinasi

\begin{tabular}{ccccc} 
Model & R & R Square & Adj. R Square & Std. error \\
\hline 1 & 0,243 & 0,590 & 0,302 & 2,880
\end{tabular}

a. Predictors: (Constant), Sanksi Perpajakan, Pemahaman Perpajakan Pelayanan Aparat Pajak

b. Dependent Variable: Persepsi Perilaku Penggelapan Pajak

Berdasarkan hasil pengujian diatas, menunjukan bahwa nilai $\mathrm{R}$ Square $\left(\mathrm{R}^{2}\right)$ sebesar 0,590 artinya persentase pengaruh Pemahaman Perpajakan (X1), Pelayanan Aparat Pajak (X2), dan Sanksi Perpajakan (X3) terhadap Penggelapan Pajak (Y) sebesar 59\% sedangkan sisanya sebesar $41 \%$ dipengaruhi oleh faktor lain yang tidak dimasukan dalam penelitian ini seperti tarif pajak, diskriminasi, dan self assessment system. 


\begin{tabular}{|c|c|c|c|c|c|}
\hline \multirow[b]{3}{*}{ Model } & \multicolumn{4}{|c|}{$\begin{array}{c}\text { Tabel } 4 \\
\text { Hasil Uji t }\end{array}$} & \multirow{3}{*}{ Sig } \\
\hline & \multicolumn{2}{|c|}{ Unstandardized Coef. } & \multirow{2}{*}{$\begin{array}{c}\text { Std. Coefficien } \\
\text { Beta }\end{array}$} & \multirow{2}{*}{$\underline{n t}$} & \\
\hline & B & Std. error & & & \\
\hline (Constant) & 10,77 & 3,21 & & 3,346 & 0,001 \\
\hline $\mathrm{X} 1$ & 0,074 & 0,03 & 0,352 & 2,100 & 0,038 \\
\hline $\mathrm{X} 2$ & 0,084 & 0,06 & 0,230 & 1,369 & 0,174 \\
\hline $\mathrm{X} 3$ & 0,073 & 0,07 & 0,095 & 0,936 & 0,351 \\
\hline
\end{tabular}

b. Dependent Variable: Persepsi Perilaku Penggelapan Pajak Sumber: data primer, diolah 2019

Diketahui nilai sig untuk pengaruh X1 terhadap $\mathrm{Y}$ adalah sebesar $0,038<0,05 \&$ nilai t hitung 2,100>1,984 sehingga dapat disimpulkan $\mathrm{H} 1$ diterima yang berarti terdapat pengaruh antara X1 terhadap Y.

Diketahui nilai sig untuk pengaruh X2 terhadap Y adalah sebesar $0,174>0,05 \&$ nilai t hitung 1,369 < 1,984 sehingga dapat disimpulkan $\mathrm{H} 2$ ditolak yang berarti tidak terdapat pengaruh $\mathrm{X} 2$ terhadap Y.

Diketahui nilai sig untuk pengaruh X3 terhadap Y adalah sebesar 0,351>0,05 \& nilai t hitung $0,936<1,984$ sehingga dapat disimpulkan H3 ditolak yang berarti tidak terdapat pengaruh X3 terhadap Y.

\subsection{Pembahasan}

\subsubsection{Pemahaman Perpajakan Terhadap Penggelapan Pajak}

Berdasarkan hasil uji t dari variabel Pemahaman Perpajakan (X1) terjadi koefisien positif dan signifikan antara pemahaman perpajakan dengan penggelapan pajak. Hal ini mengindikasikan bahwa semakin wajib pajak memahami aturan, tata cara, tentang ketentuan perpajakan ketika melakukan kewajiban perpajakan maka perilaku penggelapan pajak dipandang tidak etis untuk dilakukan.

Hasil penelitian ini sesuai dengan penelitian yang dilakukan oleh (Devi Martardi, 2016) yang menyatakan bahwa pemahaman perpajakan berpengaruh signifikan terhadap penggelapan pajak (tax evasion). Selanjutnya penelitian yang dilakukan oleh (Rachmadi, 2014) menyatakan bahwa pemahaman perpajakan berpengaruh signifikan terhadap tindakan penggelapan pajak (tax evasion). Dalam penelitian tersebut menjelaskan, apabila wajib pajak memiliki pengetahuan dan pemahaman yang baik mengenai peraturan, tata cara, dan ketentuan perpajakan dalam membayar pajak, maka wajib pajak tidak akan menganggap tindakan penggelapan pajak sebagai perilaku yang pantas dilakukan.

\subsubsection{Pelayanan Aparat Pajak Terhadap Penggelapan Pajak}

Berdasarkan hasil uji t dari variabel Pelayanan Aparat Pajak (X2) menyatakan bahwa X2 koefisien positif dan tidak signifikan antara pelayanan aparat pajak dan penggelapan pajak (tax evasion). Hal ini berarti bahwa semakin baik tingkat pelayanan aparat pajak tidak berpengaruh terhadap tingkat penggelapan pajak (tax evasion). Hasil penelitian ini sejalan dengan penelitian (Yetmi, Darmayanti, \& Muslim, 2014) yang menyimpulkan bahwa kualitas pelayanan aparat pajak tidak berpengaruh terhadap persepsi wajib pajak mengenai penggelapan pajak.

Penelitian (Dewi, 2011) menunjukan hal yang sama dimana pelayanan aparat pajak tidak mempengaruhi kesadaran wajib pajak dalam membayar pajak, namun sikap aparat pajak bersamasama dengan pembelajaran pajak dan sosialisasi perpajakan secara signifikan mempengaruhi kesadaran wajib pajak dalam membayar pajak. 


\subsubsection{Sanksi Perpajakan Terhadap Penggelapan Pajak}

Berdasarkan hasil uji t dari variabel Sanksi Perpajakan (X3) terjadi koefisien positif dan tidak signifikan antara sanksi perpajakan dengan penggelapan pajak. Hal ini berarti bahwa semakin berat sanksi perpajakan yang diberikan tidak berpengaruh positif terhadap penggelapan pajak (tax evasion). Hal ini sesuai dengan penelitian yang dilakukan oleh (Yetmi, 2014) yang menyimpulkan bahwa sanksi perpajakan tidak berpengaruh terhadap persepsi wajib pajak mengenai penggelapan pajak.

Penelitian yang dilakukan oleh (Yezzie, 2017) menunjukan hal yang serupa bahwa sanksi perpajakan tidak berpengaruh, hal ini menunjukan bahwa pengenaan sanksi perpajakan kepada pelanggar peraturan perpajakan tidak memberikan pengaruh terhadap persepsi wajib pajak mengenai penggelapan pajak.

\section{PENUTUP}

\subsection{Kesimpulan}

Berdasarkan hasil penelitian ini, maka peneliti memberikan kesimpulan sebagai berikut :

1. Variabel Pemahaman Perpajakan (X1) memiliki pengaruh positif signifikan terhadap penggelapan pajak (tax evasion) Hal ini mengindikasikan bahwa semakin wajib pajak memahami aturan, tata cara, tentang ketentuan perpajakan ketika melakukan kewajiban perpajakan maka perilaku penggelapan pajak dipandang tidak etis untuk dilakukan. Pada KPP Pratama Jayapura, pemahaman perpajakan bagi wajib pajak semakin terbantu dengan adanya beberapa loket yang diberi nama help desk. Help desk membantu wajib pajak yang mengalami kesulitan ketika membayar pajak dan membantu menjawab pertanyaan wajib pajak mengenai aplikasi perpajakan.

2. Pelayanan Aparat Pajak (X2) tidak berpengaruh positif terhadap Penggelapan Pajak (tax evasion) (Y). Dalam penelitian ini menunjukan bahwa semakin baik tingkat pelayanan aparat pajak tidak berpengaruh positif terhadap penggelapan pajak (tax evasion).

3. Sanksi Perpajakan (X3) tidak berpengaruh positif terhadap persepsi wajib pajak mengenai Penggelapan Pajak (tax evasion) (Y). Hal ini berarti hipotesis ketiga ditolak. Berdasarkan hasil penelitian yang dilakukan oleh Wahyu Rachmandi (2014), semakin besar denda yang dibebankan kepada wajib pajak akan mendorong wajib pajak untuk berperilaku tidak patuh dan semakin banyak kesempatan yang dimiliki wajib pajak untuk melakukan penggelapan pajak. Hal ini menunjukan bahwa pengenaan sanksi kepada pelanggar peraturan perpajakan tidak memberikan pengaruh terhadap persepsi wajib pajak mengenai Penggelapan Pajak.

\subsection{Saran}

\section{Saran untuk KPP Pratama Jayapura}

Variabel Pemahaman Perpajakan adalah faktor yang dapat mempengaruhi tindakan Penggelapan Pajak (tax evasion) di KPP Pratama Jayapura. Pada KPP Pratama Jayapura variabel Pemahaman Perpajakan memiliki pengaruh positif terhadap penggelapan pajak. Sebaiknya KPP Pratama Jayapura lebih memperbanyak sosialisasi mengenai jenis-jenis pajak, fungsi atau keuntungan dalam membayar pajak, tata cara pembuatan NPWP maupun cara mengisi SPT agar mudah dipahami oleh wajib pajak. Hal itu dapat dilakukan di sosial media KPP Pratama Jayapura, seperti Facebook, Twitter, Instagram, dan media sosial lainnya. Hal ini bertujuan agar pemahaman perpajakan dan kesadaran wajib pajak semakin meningkat, menurunkan kesalahan wajib pajak dan menurunkan tingkat perilaku Penggelapan Pajak ketika wajib pajak memiliki Pemahaman Perpajakan yang baik. Dengan sosialisasi tersebut, diharapkan tingkat Penggelapan Pajak semakin menurun dengan adanya tingkat Pemahaman 
Perpajakan yang baik.

\section{Saran untuk peneliti selanjutnya}

a. Penelitian selanjutnya diharapkan dapat menambah variabel bebas yang dapat mempengaruhi tindakan penggelapan pajak (tax evasion).

b. Penelitian selanjutnya diharapkan dapat melakukan penelitian lebih dari satu tempat Kantor Pelayanan Pajak sehingga data tersebut dapat dibandingkan antara satu Kantor Pelayanan Pajak dengan Kantor Pelayanan Pajak yang lain.

c. Penelitian selanjutnya diharapkan dapat membuat kuesioner penelitian dengan maksimal 5 pertanyaan.

d. Penelitian selanjutnya diharapkan untuk menggunakan rumus slovin dalam penentuan sampel.

e. Penelitian selanjutnya diharapkan memperluas objek penelitiannya dan menggunakan metode penelitian selain survey, misalnya wawancara untuk memperoleh hasil penelitian yang lebih baik

\section{Saran Untuk Wajib Pajak Orang Pribadi}

Untuk wajib pajak diharapkan untuk lebih berfikir cerdas agar tidak salah mengartikan tentang perilaku penggelapan pajak, sehingga tidakan penggelapan pajak tersebut akan menurun dengan adanya pola berfikir wajib pajak yang baik. 


\section{DAFTAR PUSTAKA}

Ajzen, I. (1991). The theory of planned behavior. Organizational Behavior and Human Decision Processes, 50(2), Vol 179-211.

Arifiani, Nisa, 2016, Pengaruh Pemahaman, Sistem Perpajakan, Persepsi Baik Pada Fiskus, dan Keadilan Terhadap Tindakan Tax Evasion, Skripsi S1, Universitas Muhammadiyah Yogyakarta, Yogyakarta, Diakses 7 Agustus 2017, dari www.repository.umy.ac.id

Arum, H. P. (2012). Riset Terdahulu. Pengaruh kesadaran WP, Pelayanan Fiskus dan Sanksi Pajak Terhadap Kepatuhan Wajib Pajak Orang Pribadi yang Melakukan Kegiatan Usaha dan Pekerjaan Bebas (Studi di wilayah KPP Pratama Cilacap). Universitas Diponegoro. Http://Ejournal-S1. Undip. Ac. Id/Index. Php/Accounting. Diakses Tanggal, 13.

Damanik, Anggita Gloria, 2015, Faktor-Faktor yang Mempengaruhi Penggelapan Pajak di Indonesia, Skripsi S1, Universitas Sumatera Utara, Medan Diakses 7 Agustus 2017, dari www.repository.usu.ac.id

Devi Martardi, 2016, Pengaruh Persepsi Wajib Pajak Orang Pribadi Terhadap Tindakan Penggelapan Pajak di Kota Surakarta, Jurnal, Universitas Islam Batik Surakarta, Surakarta, Diakses 5 Desember 2017, dari ejournal.stkip-pgri-sumbar.ac.id

Dewi, M. R. (2011). Persepsi wajib Pajak atas Pengenaan Pajak Penghasilan: Anteseden dan Konsekuensinya. Skripsi Tidak Dipublikasikan, Program S1 Akuntansi Universitas Diponegoro.

Ghozali, I. (2006). Aplikasi analisis multivariate dengan program SPSS. Badan Penerbit Universitas Diponegoro.

Glaser, M. A., \& Hildreth, W. B. (1999). Service delivery satisfaction and willingness to pay taxes: Citizen recognition of local government performance. Public Productivity \& Management Review, Vol 48-67.

Jatmiko, A. N. (2006). Pengaruh Sikap Wajib Pajak pada Pelaksanaan Sanksi Denda, Pelayanan Fiskus dan Kesadaran Perpajakan terhadap Kepatuhan Wajib Pajak (Studi Empiris terhadap Wajib Pajak Orang Pribadi di Kota Semarang). Program Pasca Sarjana Universitas Diponegoro.

Kant, I. (1996). The metaphysics of morals.

Krueger, N. F., \& Carsrud, A. L. (1993). Entrepreneurial intentions: applying the theory of planned behaviour. Entrepreneurship \& Regional Development, 5(4), Vol 315-330.

Kurniati, Herlangga \& Pratiwi, R. (2017). Riset Terdahulu. Pengaruh Pemahaman Perpajakan, Self Assessment System, Dan Tarif Pajak Terhadap Tindakan Penggelapan Pajak (Tax Evasion)(Studi Kasus Pada Wajib Pajak Terdaftar Di Kpp Pratama Ilir Timur Palembang).

McGee, R. W. (2006). Three views on the ethics of tax evasion. Journal of Business Ethics, 67(1), Vol $15-35$. 
Neuman, L. W. (2007). Social Research Methods, 6/E. Pearson Education India.

Nurmantu, S. (2005). Pengantar perpajakan. Yayasan Obor Indonesia.

Nurmantu, S. (2007). Faktor-Faktor yang mempengaruhi Pelayanan Perpajakan. Jurnal Ilmu Adminstrasi Dan Organisasi, Bisnis \& Birokrasi, Vol 15(1).

Prananjaya, K. P. (2018). Dapatkah Sanksi Pajak dan Tax Amnesty Memitigasi Tindakan Ketidakpatuhan Pajak?: Bukti Eksperimen di Indonesia. Berkala Akuntansi Dan Keuangan Indonesia, 3(2), Vol 23-45.

Prasetyo, T. (2010). Hukum Pidana. Rajawali Pers, Jakarta.

Pujianto, Dwi Indryani, 2014, Persepsi Wajib Pajak Orang Pribadi Atas Efektifitas Self Assessment System, dan Sanksi Pajak Dalam Keterkaitannya Dengan Tindakan Tax Evasion, Skripsi S1, Universitas Hasanuddin, Makassar, Diakses 7 Agustus 2017, dari www.core.ac.uk

Rachmadi, Wahyu, 2014. Riset Terdahulu. Faktor-Faktor yang Mempengaruhi Persepsi Wajib Pajak Orang Pribadi Atas Perilaku Penggelapan Pajak, Skripsi S1, Universitas Diponegoro, Semarang, Diakses 7 Agustus2017, dari www.eprints.undip.ac.id

Rahayu, S. K. (2010). Perpajakan Indonesia: Konsep dan Aspek Formal. Yogyakarta: Graha Ilmu.

Rahman, I. S. (2013). Riset Terdahulu. Pengaruh keadilan, sistem perpajakan, diskriminasi, dan kemungkinan terdeteksi kecurangan terhadap persepsi wajib pajak mengenai etika penggelapan pajak (tax evasion).

Resmi, S. (2009). Perpajakan teori dan kasus. Jakarta: Salemba Empat.

Soenaryo, J. (2015). Analisis Pengaruh Responsiveness, reliability, Assurance, Emphaty, Dan Tangible Agen PT Aj Sequislife Terhadap Kepuasan Pelanggan Pada Cabang Surabaya-Trusty. Agora, 3(1), Vol 23-28.

Sugiyono, D. R. (2006). Statistika untuk penelitian. Bandung: CV. Alfabeta.

Sugiyono, P. (2005). Memahami penelitian kualitatif. Bandung: Alfabeta.

Sulistiani, I. (2016). Faktor-faktor yang mempengaruhi persepsi wajib pajak orang pribadi melakukan tax evasion (studi empiris pada wp op di kabupaten purbalingga). Universitas Negeri Semarang.

Suminarsasi, W. (2012). Supriyadi, 2011. Riset Terdahulu. Pengaruh Keadilan, Sistem Perpajakan, dan Dis-kriminasi Terhadap Persepsi Wajib Pajak Mengenai Etika Penggelapan Pajak (Tax Evasion). Jurnal Simposium Nasional Akuntansi XV.

Supadmi, N. L. (2009). Meningkatkan kepatuhan wajib pajak melalui kualitas pelayanan. Jurnal Ilmiah Akuntansi Dan Bisnis. 
Wallschutzky, I. G. (1984). Possible causes of tax evasion. Journal of Economic Psychology, 5(4), Vol 371-384.

Waluyo, 2013, Perpajakan Indonesia, Jakarta, Salemba Empat4 Wicaksono, Muhammad Ary, 2014, Pengaruh Persepsi Sistem Perpajakan, Keadilan Pajak, Diskriminasi Pajak, dan Pemahaman Perpajakan Terhadap Perilaku Penggelapan Pajak, Diakses 7 Agustus 2017, dari www.eprints.undip.ac.id

Yetmi, S. Y., Darmayanti, Y., \& Muslim, R. Y. (2014). Faktor-Faktor Yang Mempengaruhi Persepsi Wajib Pajak Mengenai Penggelapan Pajak. Jurnal Ilmiah, 5(1), Vol 1-15.

Yezzie, C. (2017). Pengaruh keadilan, sistem perpajakan, pemahaman perpajakan dan sanksi pajak terhadap persepsi wajib. 